\title{
Isolated thyroid metastasis from renal cell carcinoma
}

\author{
Ali Solmaz1 Ali Muhammedoğlu², Serdar Altınay², Candaș Erçetin¹, Erkan Yavuz¹, Osman Bilgin Gülçiçek', Șenay Yalçın², \\ Yeșim Erbil ${ }^{3}$ \\ Metastatic neoplasms of the thyroid are uncommon when compared to primary tumors of the gland. Renal cell \\ carcinoma (RCC) is a highly aggressive tumor of the urinary system. It can spread all over the body. Isolated solitary \\ metastases of RCC to the thyroid are very rarely observed. A 64-year-old woman with a history of left radical ne- \\ phrectomy for RCC, was referred to our clinic with palpable thyroid nodule. Ultrasound confirmed the nodule on \\ the left lobe. Histopathological examination of the thyroidectomy specimen revealed that there were two solitary \\ metastasis of RCC. No other distant metastasis were detected. Metastatic tumors of the thyroid gland are very rare. \\ When patients with thyroid nodule are referred to our clinic with the history of other malignancies, we must con- \\ sider metastasis. Thyroidectomy is recommended in the case of isolated thyroid metastasis of RCC. \\ Keywords: Renal cell carcinoma, metastasis, thyroidectomy
}

Cite this paper as: Solmaz A, Muhammedoğlu A, Altınay S, Erçetin C, Yavuz E, Gülçiçek OB, Yalçın Ş, Erbil Y. Isolated thyroid metastasis from renal cell carcinoma. Turk J Surg 2017; 33(2): 110-112

'Clinic of General Surgery, Bağcılar Training and Research Hospital, İstanbul, Turkey ${ }^{2}$ Clinic of Pathology, Bağcilar Training and Research Hospital, İstanbul, Turkey

${ }^{3}$ Department of General Surgery, İstanbul University İstanbul School of Medicine, İstanbul, Turkey

Address for Correspondence Ali Solmaz

e-mail: solmazali@hotmail.com

Received: 28.10.2014

Accepted: 27.11.2014

Available Online Date: 06.07.2015

@ Copyright 2017

by Turkish Surgical Association

\section{INTRODUCTION}

Renal cell carcinomas (RCC), (also known as renal adenocarcinoma) are most common cancer type of kidneys originating from proximal tubules. It accounts for $2-3 \%$ of all adult malignancies and is also the seventh most common cancer in men and the ninth most common cancer in women (1). Renal cell carcinoma can metastasize to all organs hematogenously. In $30 \%$ of the cases, metastasis is present at diagnosis (2). The most common sites of metastasis are lungs, bone, lymph nodes, and liver (3). Gastric, brain, and skin involvement are also rarely seen. Although the thyroid gland is the second most common vascular organ of the body following the adrenal glands, metastasis of RCC is seen very rarely. In the autopsy series, tumors that metastasize to the thyroid are generally lung, breast, kidney, and head and neck (4). Isolated thyroid metastasis of RCC is very rare. When present, metastatic RCC mimics primary tumors of the thyroid gland. Renal cell carcinoma generally presents as a mass in the neck.

We describe herein a patient with solitary metastasis to the thyroid, who had undergone a left nephrectomy for RCC 17 months previously.

\section{CASE PRESENTATION}

A 64-year-old woman with a history of 15 years of non-toxic multinodular goitre was consulted to our clinic from urology. She had no other symptoms such as dysphagia or dyspnea. A physical examination revealed palpable nodules on both sites of the thyroid gland. She had a left nephrectomy operation 17 months earlier. She was followed-up without any other treatment. On follow-up, thoracoabdominal computed tomography (CT) showed enlargement of the thyroid gland and hypoechoic nodule with a diameter of $22 \mathrm{~mm}$ in the left lobe of the thyroid gland (Figure 1). Ultrasound was performed on this neck. There was heterogeneity of the gland and there was a $22 \mathrm{~mm}$ hypoechoic nodule in the left lobe. The result of the radiological features and the thyroid volume led us to operate the patient. She did not accept the fine needle aspiration cytology.

A total thyroidectomy was performed in our clinic. Parathyroid glands and recurrent nerves were recognized and preserved. Macroscopic examination of the specimen showed that there is a $2 \mathrm{~cm}$ and $0.5 \mathrm{~cm}$ nodule and an ill-defined $0.8 \mathrm{~cm}$ nodule on the left lobe. The right lobe was normal. Microscopic examination revealed that there is lymphocytic thyroiditis and nodular hyperplasia in the nodule that is $2 \mathrm{~cm}$ in diameter, but there are some atypical cells with clear cytoplasm and large vesicular nuclei and prominent nucleoli in the nodules $(0.5 \mathrm{~cm}$ diameter). The same atypical cells were also found in an area of $0.8 \mathrm{~cm}$ in diameter, in the same lobe out of the nodules described. We learned from the history of the patient that she had left nephrectomy 16 months ago for pT3 RCC. Immunohistochemical examination showed strong immunoreactivity with RCC and CD10 and 
vimentin. These neoplastic cells were negative for thyroid transcription factor-1 (TTF-1). These findings proved that these two nodules, which are 0.8 and 0.5 in diameter, are the metastasis of RCC (Figure 2). After the operation, the patient was referred to the oncology clinic.

\section{DISCUSSION}

Tumors of thyroid glands are mostly primary tumors, which are papillary, follicular, medullary, and anaplastic carcinomas in the order of frequency. On the other hand, metastatic thyroid gland tumors are seen very rarely and account for 2-3\% of the thyroid malignancies (5). Common primary tumors metastasizing to the thyroid are lung, breast, kidney, and head and neck (4). These secondary thyroid gland tumors are found in $5-24 \%$ of the autopsy series. Metastases to thyroid in these autopsy series are generally multifocal, but in clinical series, metastases are solitary and $<15 \mathrm{~mm}$ in size (6). Our patient displays similarities with literature in terms of the tumor diameter.

According to the article published by Chung et al. (7), the most common non-thyroid malignancies metastasizing to the thyroid are RCC (48.1\%), colorectal $(10.4 \%)$, lung $(8.3 \%)$, breast carcinoma (7.8\%), and sarcoma (4.0\%). Metastases are generally nodular (44.2\%) and are more common in females as observed in our case.

Renal cell carcinoma is the most common and very aggressive tumor of the urinary system. Its incidence increases with age. Until the widespread use of screening tests in recent years, many of the detected RCC had been metastasized. However, nowadays, by the use of these screening tests, $70 \%$ of them are detected as an incidental finding (8). This induces early detection of the cancer. However, despite early detection and surgical treatment, patients do not recover from the disease. We can see the metastasis of RCC even 10-20 years after diagnosis. Distant metastasis may be seen in one out of three patients. Our patient had left nephrectomy 16 months ago for pT3 RCC.

Renal cell carcinoma spreads hematogenously or through the lymphatic pathway to distant organs. The metastatic pathway is unpredictable for RCC. The lung, bone, liver, adrenal glands, brain, and skin are the most common sites of metastasis (8). The less frequent distant metastatic sites are orbit, parotid gland, nasal and paranasal cavities, tongue and tonsils, heart, skin, ovaries, uterus, testis, and thyroid glands.

The clinical findings of the primary and metastatic cancers of the thyroid gland are similar. We may not be able to dif- ferentiate them even with radiological evidences. Sometimes, fine needle aspiration biopsy may not be helpful in differentiating primary tumor from metastasis. However, if the pathologist is aware of the oncologic history of the patient, then by the use different antibodies and immunohistochemical studies, he/she may discriminate the pathology (9).

Thyroidectomy is recommended for isolated solitary thyroid metastasis of RCC. The mean survival rate after surgery is variable in the literature because the information about survival is limited to case reports. Heffess et al. (9) reported a series of 36 cases. According to this series, the mean overall survival period was 12.3 years from nephrectomy and 6.4 year from the date of thyroid metastasis. Machens and Dralle (10) reported that after definitive surgery of the thyroid metastasis of $\mathrm{RCC}$, the mean survival rate may rise up to $30-60 \%$. Considering that our patient, who was at an advanced age and presented with two nodules at a diameter of $5 \mathrm{~mm}$ and $8 \mathrm{~mm}$, would have a poor prognosis, we are monitoring her closely in order to share her survival data in future studies.

\section{CONCLUSION}

Renal cell carcinoma can metastasize to distant organs even after many years. The thyroid gland is rarely affected by this. When the patient referred to our clinic with the thyroid nodule, we had data about the oncological history of the patient. If the patient had isolated thyroid metastases from RCC, thyroidectomy must be performed to improve prognosis.

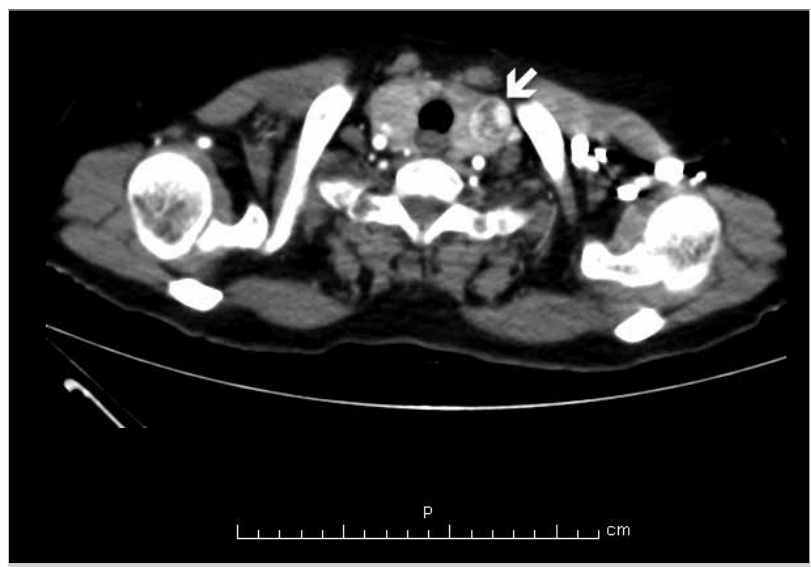

Figure 1. Axial computed tomography image of the neck: the white arrow indicates a mass of size $2.2 \mathrm{~cm}$ in the left lobe of the thyroid gland

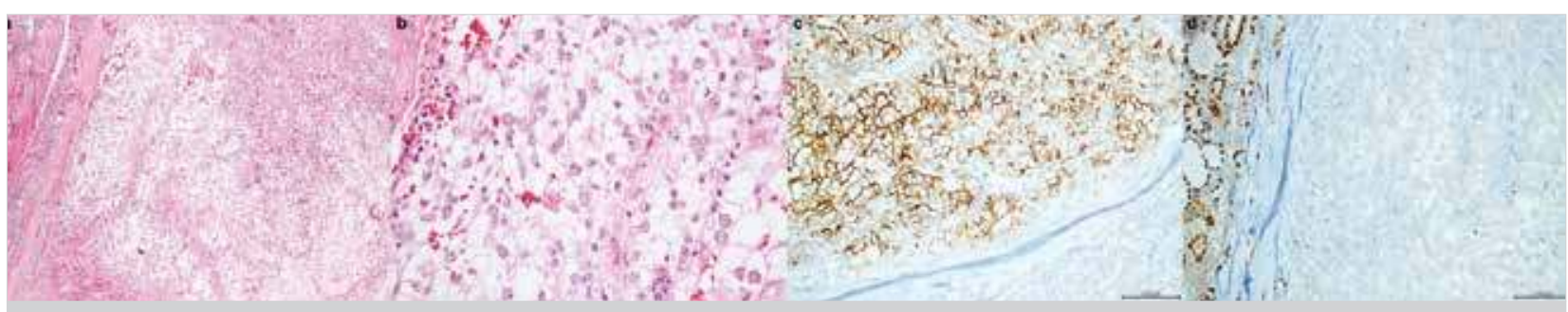

Figure 2. a-d. (a) The tumor area with clear cell morphology in the thyroid gland ( $\times 100 ; \mathrm{H} \& \mathrm{E})$. (b) High power illustration ( $\times 400 ; H \& E$ ). Differing from the surrounding thyroid tissue, the tumor tissue showed strong immunoreactivity with CD 10 antibody (c $\times 200)$, but negative with TTF-1 antibody $(d \times 200)$ 
Informed Consent: Written informed consent was obtained from the patient who participated in this case.

Peer-review: Externally peer-reviewed.

Author Contributions: Concept - A.S., S.A.; Design - A.S., O.B.G., S.A.; Supervision - Y.E.; Funding - C.E., A.S.; Materials - A.M., S.A., Ş.Y.; Data Collection and/or Processing - E.Y., A.S.; Analysis and/or Interpretation - A.S., O.B.G., C.E.; Literature Review - E.Y., A.S.; Writer - A.S.; Critical Review - Y.E.; Other - A.S., O.B.G., S.A.

Conflict of Interest: No conflict of interest was declared by the authors.

Financial Disclosure: The authors declared that this study has received no financial support.

\section{REFERENCES}

1. Rini B, Campbell S, Escudier B. Renal cell carcinoma. Lancet 2009; 373: 1119-1132. [CrossRef]

2. De Stefano R, Carluccio R, Zanni E, Marchiori D, Cicchetti G, Bertaccini $A$, et al. Management of thyroid nodules as secondary involvement of renal cell carcinoma: case report and literature review. Anticancer Res 2009; 29: 473-476.
3. Hoffmann NE, Gillett MD, Cheville JC, Lohse CM, Leibovich BC, Blute ML. Differences in organ system of distant metastasis by renal cell carcinoma subtype. J Urol 2008; 179: 474-477. [CrossRef]

4. Medas F, Calo PG, Lai ML, Tuveri M, Pisano G, Nicolosi A. Renal cell carcinoma metastasis to thyroid tumor: a case report and review of the literature. J Med Case Rep 2013; 7: 265. [CrossRef]

5. Bohn OL, Casas LE, Leon ME. Tumor-to-tumor metastasis: renal cell carcinoma metastatic to papillary carcinoma of thyroid. Report of a case and review of the literature. Head Neck Pathol 2009; 3: 327-330. [CrossRef]

6. De Lellis RA, Lloyd RV, Heitz PU, Eds CE. World Health Organization Classification of Tumours. Pathology and Genetics of Tumours of Endocrine Organs. IARC Press, Lyon, France, 2004.

7. Chung AY, Tran TB, Brumund KT, Weisman RA, Bouvet M. Metastases to the thyroid: a review of the literature from the last decade. Thyroid 2012; 22: 258-268. [CrossRef]

8. Koul H, Huh JS, Rove KO, Crompton L, Koul S, Meacham RB, et al. Molecular aspects of renal cell carcinoma: a review. Am J Cancer Res 2011; 1: 240-254.

9. Heffess CS, Wenig BM, Thompson LD. Metastatic renal cell carcinoma to the thyroid gland: a clinicopathologic study of 36 cases. Cancer 2002; 95: 1869-1878. [CrossRef]

10. Machens A, Dralle H. Outcome after thyroid surgery for metastasis from renal cell cancer. Surgery 2010; 147: 65-71. [CrossRef] 